\title{
Clinical Manifestations and Molecular Investigation of 50 Patients with Williams Syndrome in the Greek Population
}

\author{
STELLA AMENTA, CHRISTALENA SOFOCLEOUS, ANGELIKI KOLIALEXI, \\ LORETTA THOMAIDIS, SOTIRIS GIOUROUKOS, EMMANUEL KARAVITAKIS, \\ ARIADNI MAVROU, SOPHIA KITSIOU, EMMANUEL KANAVAKIS, AND HELEN FRYSSIRA \\ Medical Genetics [S.A., C.S., A.K., E.Kar., A.M., S.K., E.Kan., H.F.], Athens University School of \\ Medicine, Athens, Greece; and Developmental Assessment Unit of the 1st Department of Pediatrics [L.T.] \\ Athens University School of Medicine, Aghia Sophia Children's Hospital, Athens, Greece
}

\begin{abstract}
Williams syndrome (WS) is a well-recognized neurodevelopmental disorder manifested by both connective tissue and CNS abnormalities. The study depicts the 8-y experience and follow-up of 50 Greek children with the clinical diagnosis of WS. Clinical data on the facial features and cardiovascular, endocrinologic, and neurodevelopmental evaluation are presented. The most consistent findings were dysmorphic features (100\%), followed by dental anomalies (90\%) and hyperacousis (90\%). Only eight of 50 children had severe cardiovascular defects that required surgical intervention during the first year of life. Supravalvular aortic stenosis was less frequent $(28 \%)$ than shown in the literature. Severe hypertension was noticed in $22 \%$ of our patients, and infantile hypercalcemia was noticed in $6 \%$. Twelve percent of our patients showed an elevation of CPK. Most children presented with moderate to severe mental retardation with IQ ranging from 20 to 85 . Elastin hemizygosity was detected by fluorescence in situ hybridization. Dinucleotide repeat
\end{abstract}

\section{ABSTRACT}

polymorphism analysis was performed in an attempt to correlate phenotype with genotype. The origin of deletions was more frequently maternal (59\%), and a more severe phenotype seemed to be associated with those deletions. This is the first report on WS patients in the Greek population. (Pediatr Res 57: 789-795, 2005)
BMI, body mass index

\section{Abbreviations}
DNRP, dinucleotide repeat polymorphism
FISH, fluorescence in situ hybridization
LCR, low-copy repeat
PS, pulmonary stenosis
RFLP, restriction fragment length polymorphism
SVAS, supravalvular aortic stenosis
WS, Williams syndrome

Williams syndrome (WS; OMIM 194050) was first described in 1961 by Williams et al. (1) as a congenital developmental disorder involving both connective and central nervous systems. It is characterized by distinctive facial features, growth delay, mental retardation with typical neurobehavioral profile, cardiovascular anomalies, and occasional infantile hypercalcemia. Other features include feeding difficulties during infancy, poor visual motor skill abilities, hyperacusis, hoarse voice, joint hyperextensibility, and stellate pattern of iris (2).

The estimated frequency of WS is $\sim 1$ in 20,000, and the syndrome is mainly sporadic, although there are reports of a few cases following autosomal dominant inheritance (3-5). WS is one of the contiguous gene syndromes. In 1995, Nick-

Received June 4, 2004; accepted September 27, 2004.

Correspondence: Helen Fryssira, M.D., M.Sc., Medical Genetics, Athens University, School of Medicine, Choremio Research Laboratory, "Aghia Sophia" Children's Hospital, Goudi, P.C. 11527, Athens, Greece; e-mail: efrysira@cc.uoa.gr.

DOI: 10.1203/01.PDR.0000157675.06850.68 erson et al. (6) stated that haploinsufficiency of multiple genes, at the 7q11.23 locus, may contribute to the phenotypic features. At least 19 genes, apart from ELN (STX1A, LIMK1, RFC2, FZD3, FKBP6, WBSCR9/WSTF, CYCLN2, GTF3, etc.) are included in the commonly deleted region, which is $1.5-1.7 \mathrm{Mb}$ in size and contains the polymorphic markers D7S489B and D7S1870 $(4,7)$. Hemizygosity at the elastin locus $(E L N)$ on chromosome 7 occurs in $\sim 95 \%$ of WS patients $(4,8)$. ELN gene deletions that result in loss of elastin function are solely responsible for the pathogenesis of the cardiovascular aspects of the disorder (9-13).

The LIMK1 gene lies telomeric to the ELN gene and has been implicated in the cognitive deficit of the syndrome because it is deleted in all WS patients $(6,12,14-16)$. Wang et al. (17) found that LIMK1 and neuroregulin are co-localized at the neuromuscular synapse, suggesting that LIMK1-like neuroregulin may play a role in synapse formation and maintenance. The LIMK1 protein is also implicated in the function of actin and apoptosis (18). 
Diagnosis of WS relies mainly on recognition of the characteristic facial features, but the variability of the syndrome often makes clinical delineation difficult, especially during the early months of life. Identification of an elastin gene deletion by molecular cytogenetic techniques [fluorescence in situ hybridization (FISH)] as well as by DNA analysis confirms the clinical diagnosis (8).

The present report describes phenotypic and genotypic data in a group of 50 Greek patients and adults with the clinical diagnosis of WS, aged from 3 mo to $30 \mathrm{y}$. Special consideration was given to the long-term complications and early intervention programs, as their life expectancy has been increased.

\section{METHODS}

This 8 y study (1996-2004) initially consisted of 65 children and adolescents ( 39 boys and 26 girls) who were referred consecutively to the Department of Medical Genetics of Athens University Medical School because of developmental delay and/or heart disease with the possible diagnosis of WS Fifty patients (28 boys and 22 girls) met the clinical criteria of WS and underwent laboratory investigation. None of the parents had the clinical features of WS, indicating that all cases were de novo presentations. One set of monozygotic twins participated in the study. All families were of Greek origin, with the exception of two mothers (patients 17 and 24). Full medical records and pictures of all patients classified according to age and phenotype were kept for their follow-up, which included detailed clinical and laboratory assessment. The study was approved by the Institutional Review Board of Athens University, and an informed consent regarding DNA studies was obtained from all families.

For obtaining uniform clinical data, a questionnaire was designed according to the guidelines published by the American Academy of Pediatrics and growth parameters were plotted on WS growth charts (2). Medical problems were classified along with the dysmorphic features and recorded (Table 1). All children underwent the following:

1. Physical (including growth parameters) and neurologic examination

2. Cardiologic evaluation (clinical, ECG, echocardiogram) and four-limb blood pressure measurements

3. Multidisciplinary developmental assessment and intervention. Mental retardation was classified into severe (IQ <40), mild/moderate (IQ 40-75), and borderline (IQ >75).

4. Genitourinary system evaluation (ultrasonography of bladder and kidneys, renal function, and urinalysis studies)

5. Ophthalmologic evaluation

6. Endocrine testing (thyroid function, growth hormone, sex hormones)

7. Hearing assessment

8. Biochemical profile

For the last $8 \mathrm{y}$, all children have been followed up with routine examinations and early intervention programs according to their age group, and, when necessary, guidance and vocational training were offered.

Cytogenetic and FISH studies. Blood was collected, after informed consent, from 50 children and their parents. Chromosome analysis by conventional G-banding technique was performed in all patients. Two-color FISH was applied for the detection of hemizygosity of the elastin gene on metaphase spreads and nuclei using the ELN chromosome specific probe (Oncor; Appligene, France) on $7 \mathrm{q} 11.23$. Hybridization and detection procedures were according to the manufacturer's protocol. The locus D7Z1 served as a control for chromosome 7.

Molecular studies. DNA was extracted from peripheral blood lymphocytes of 46 of 50 patients and their parents using the "salting out" method (19). Four families refused to provide blood samples. Dinucleotide repeat polymorphism (DNRP) analysis was performed for the characterization of six intragenic polymorphic markers along the critical WS region at 7q11.23. Loci D7S489B, D7S2476, D7S613, D7S2472, D7S1870, and D7S489A, which flank and encompass the elastin gene, were used for genotypic analysis (Fig. 1). Primer sequences and PCR conditions were as retrieved from the NCBI genbank (www.ncbi.nlm.nih.gov/htbinpost/Entrez/). Primers were custom-made, nonradioactive Texas Red labeled (Genset SA, Paris, France). The PCR products were fractionated by electrophoresis, using the Vistra 725 Automated Sequencer. Comparative haplotype analysis and data processing were performed with the use of FragmeNT Analysis v1.1 software (Molecular Dynamics, Amersham, UK).
Table 1. Clinical data of 50 WS patients

\begin{tabular}{|c|c|}
\hline Clinical features & $n /$ frequency $(\%)$ \\
\hline Male/female & $28 / 22$ \\
\hline Prematurity & $12 / 50(24)$ \\
\hline SfGA & $7 / 50(14)$ \\
\hline Perinatal problems & $25 / 50(50)$ \\
\hline Feeding difficulties & $35 / 50(70)$ \\
\hline Growth retardation & $33 / 50(66)$ \\
\hline \multicolumn{2}{|l|}{ Mental retardation } \\
\hline Severe & $3 / 50(6)$ \\
\hline Mild/moderate & $44 / 50(88)$ \\
\hline Borderline & $3 / 50(6)$ \\
\hline Behavior/personality traits & $47 / 50(94)$ \\
\hline Hyperacousis & $45 / 50(90)$ \\
\hline \multicolumn{2}{|l|}{ Neurologic } \\
\hline Hypotonia & $36 / 50(72)$ \\
\hline $\begin{array}{l}\text { Fine motor and oromotor } \\
\text { dysfunction }\end{array}$ & $34 / 50(68)$ \\
\hline Reflex activity & $16 / 50(32)$ \\
\hline Microcephaly & $16 / 50(32)$ \\
\hline Seizures & $4 / 50(8)$ \\
\hline $\mathrm{CPK}$ & $6 / 50(12)$ \\
\hline Dysmorphic features & $50 / 50(100)$ \\
\hline Cardiovascular & $31 / 50(62)$ \\
\hline SVAS & 14 \\
\hline PS & 9 \\
\hline SVAS + PS & 5 \\
\hline M & 3 \\
\hline Hypertension & $11 / 50(22)$ \\
\hline Genitourinary & $10 / 50(20)$ \\
\hline Ocular & $24 / 50(48)$ \\
\hline \multicolumn{2}{|l|}{ Endocrine } \\
\hline Precocious puberty & $8 / 50(16)$ \\
\hline Thyroid & $20 / 50(40)$ \\
\hline $\mathrm{GH}$ & $4 / 50(8)$ \\
\hline Skeletal and connective tissue & $30 / 50(60)$ \\
\hline Dental & $45 / 50(90)$ \\
\hline Hypercalcemia & $3 / 50(6)$ \\
\hline
\end{tabular}

SfGA, small for gestational age; M, mitral valve prolapse.

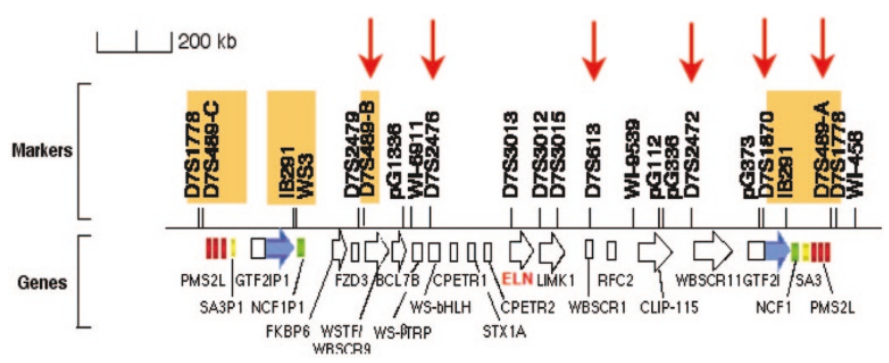

Figure 1. Physical map of the region 7q11.23. The elastin gene is shown in red. The polymorphic markers used are indicated with red arrows.

\section{RESULTS}

The main clinical and laboratory findings of our patients are summarized in Table 1. The characteristic facial features of the syndrome were present in all 50 cases. Most prominent were periorbital fullness, malar flattening and full sagging cheeks, wide mouth with prominent lower lips, broad nasal tip, broad forehead, and long philtrum.

Twenty-five of 50 patients experienced perinatal problems such as prematurity (24\%), low birth weight (14\%), respiratory distress syndrome $(6 \%)$, and jaundice $(20 \%)$. Fifteen of 50 
were born by cesarean section. Feeding difficulties and failure to thrive within the first year of life was a typical complaint of their parents (35 of 50).

At diagnosis, most children had short stature (33 of 50). Seven of 50 patients (patients 3, 6, 14, 27, 35, 41, and 47) were remarkably short $(<2 \mathrm{SD})$. Four patients (patients 3, 6, 14, and 27 ) underwent a glucagon and clonidine provocation test and received supplementation therapy with growth hormone. Microcephaly was noticed in 16 of 50 patients.

All children had some degree of mental retardation, with IQs ranging between 20 (patient 9) and 85 (patients 25,30 , and 48 ). The majority exhibited outgoing, gregarious, overfriendly personalities. Only two patients (1 and 9) did not show the typical behavioral profile, because they had severe retardation with autistic features such as stereotyped mannerisms, isolation tendencies, and frequent temper tantrums. On the other end of the spectrum, the three patients with the highest IQ exhibited almost normal behavior. Hyperactivity and distractibility were very common manifestations, especially in younger patients. Forty of 50 patients had sleep disturbances that seemed to improve with time. Hyperacousis was the most consistent finding (45 of 50) and was evident mainly in the first $5 \mathrm{y}$ of life. Hypotonia, ranging from mild to severe, was observed in 36 of 50 patients, with the most significant manifestation being the delay in walking. Generalized tonic-clonic seizures were noticed in only three patients (patients 8, 18, and 35); in one of them, it was a result of hyperpyrexia, whereas in the other two, anoxia was the triggering factor. One patient (patient 21) experienced absences. All of these patients were under anticonvulsant therapy for a limited period. Brain computed tomography scan was normal in all of our WS patients.

All patients had a systolic heart murmur as neonates. Cardiologic evaluation and echocardiography revealed supravalvular aortic stenosis (SVAS) in 14 of 50, pulmonary stenosis (PS) in nine of 50, mitral valve prolapse in three of 50, and had both SVAS and PS in five of 50. Eight patients with congenital heart defect underwent surgery. Nineteen of 50 children had no cardiovascular defect, even though heart murmurs were identified in the neonatal period. Hypertension was an early manifestation in 11 of 50 patients, and all required medication. Two male and four female adults are undergoing intensive monitoring for hypertension. Hypercholesterolemia was evident in patient 28.

The majority of the children had enuresis, and 10 of 50 had urinary infections and/or vesicoureteral reflux. The rest had normal renal ultrasound.

Ocular findings were present in $48 \%$, such as strabismus and stellate pattern of iris. Patients 3, 35, and 38 underwent surgical correction of strabismus. A 5-y-old boy, patient 31, had a remarkable blepharoptosis and in the biochemical workout was found to have elevated CPK. Five more children also had elevated CPK.

Hypothyroidism was diagnosed in 19 of 50 patients. One child showed congenital hypothyroidism (patient 5), 14 had subclinical hypothyroidism with only elevated TSH, and four were under treatment for hypothyroidism at the time of presentation. All of these patients were tested for the presence of antibodies. In only two females (patients 25 and 38) were antimicrosomal and antithyroid globulin antibodies detected. Patient 25 had hyperthyroidism. Precocious puberty was clinically observed in eight patient and was endocrinologically verified with FSH, LH, and Prl (LH response $>$ FSH response in LHRH test). Puberty was arrested in three patients (patient 10,14 , and 23).

Soft tissue manifestations such as skin hyperelasticity, inguinal hernias, hypo- and/or hyperpigmentation, slopping shoulders, joint laxity, and hernias were a frequent finding as they were present in 30 of 50 children. Twelve patients underwent surgical repair of inguinal hernias. Five children exhibited arthralgias (patients 4, 10, 12, 20, and 41), and four showed a mild degree of kyphosis (patients 9, 12, 38, and 50).

Forty-five of 50 children had dental anomalies such as small crooked teeth, caries, and excessive interdental spacing with malocclusion. Infantile hypercalcemia was found in only five patients (patients 12, 31, 32, 40, and 41).

Laboratory data. Karyotypic analysis was normal in all 50 cases. FISH in metaphase spreads and interphase nuclei showed deletion of the elastin gene in all but one patient, which was inconclusive.

Results of genotyping 46 of 50 patients for the six polymorphic loci studied are shown in Fig. 2. Molecular analysis demonstrated lack of the maternal allele in 27 (59\%) patients and the paternal in $17(37 \%)$. Figure 3 shows the deletion of the maternal allele in three different families, including the set of twins. In 44 of 46 patients, the findings were consistent for all

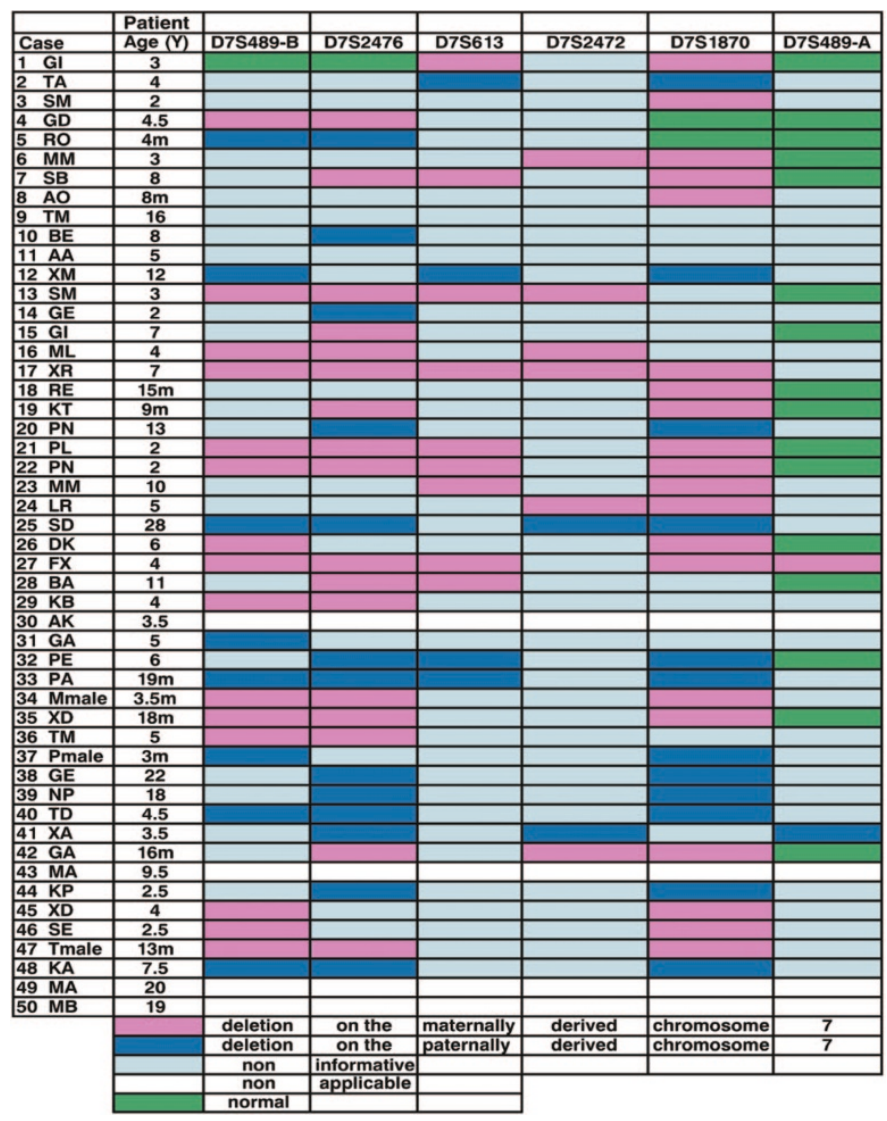

Figure 2. Results of genotyping in $46 \mathrm{WS}$ patients for six polymorphic loci (markers are ordered centromere to telomere). 

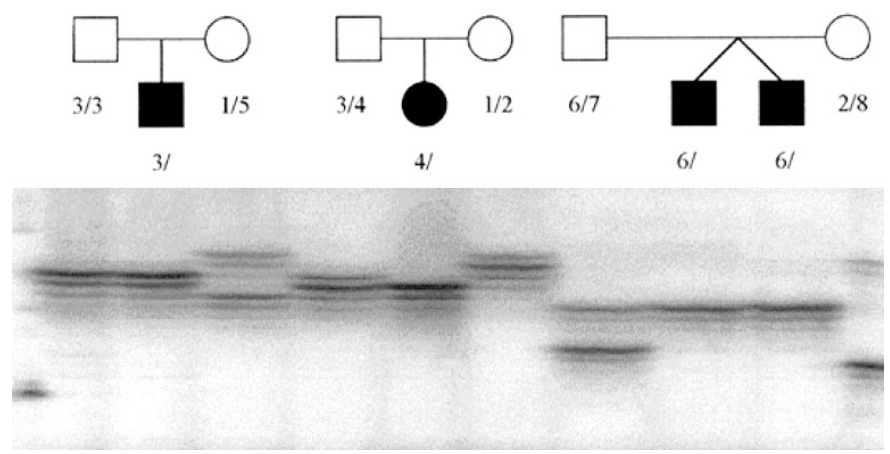

Figure 3. Polymorphic marker typing in three different families (including the family with the twins). The alleles are arbitrary. In all cases, the deletions are of maternal origin of the marker D7S1870.

informative loci, whereas two (4\%) patients (9 and 11) were noninformative for all loci tested. In Fig. 4, graphic analysis of the haplotypes is recorded.

\section{DISCUSSION}

In 1993, Ewart et al. (8) and Morris et al. (5) correlated the deletion at 7q11.23 with WS and SVAS, as a result of heterozygosity at the elastin locus. Later, a common region of deletion was described in 200 WS patients, and so far, it has not been clarified whether there is any imprinting effect (15). The genome segments involved in several contiguous gene syndromes have been shown to be flanked by low-copy repeats (LCRs). LCRs facilitate rearrangements between two homol-
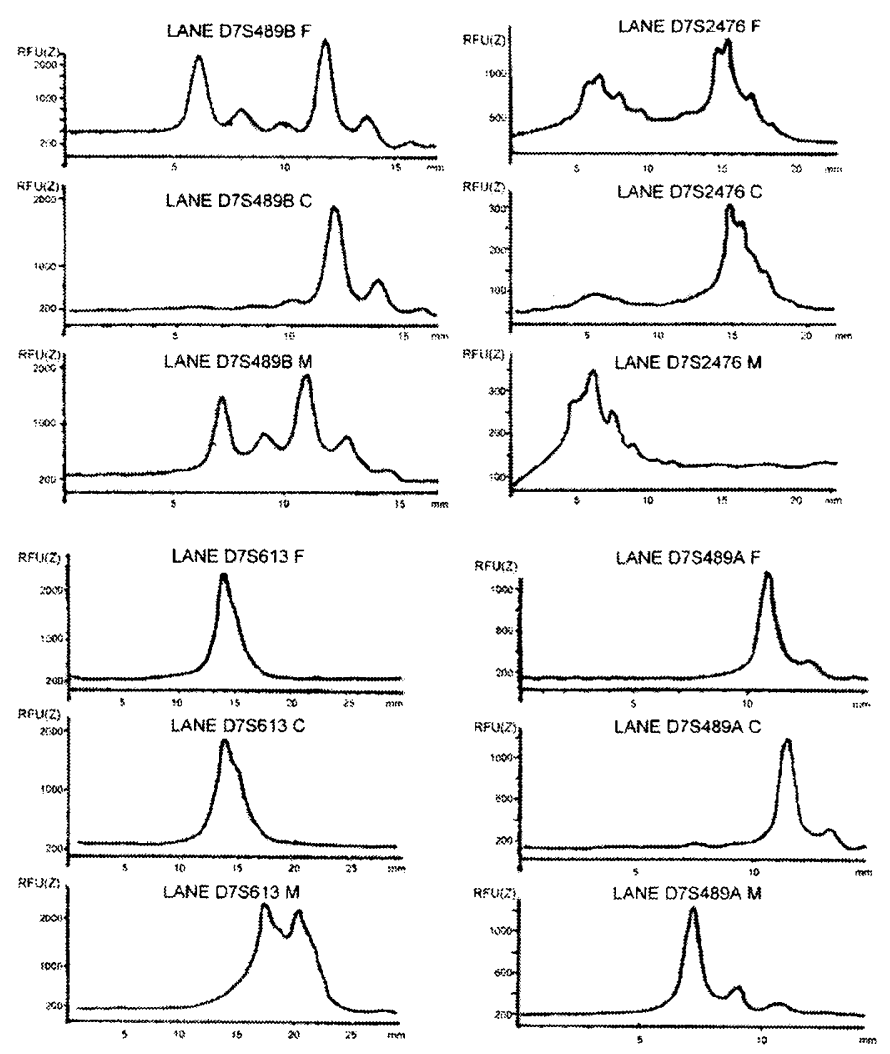

Figure 4. Graphic analysis of the haplotypes of the polymorphic markers D7S489-B, D752476, D7S613, and D7S489-A. ogous chromosomes causing genomic instabilities, which could progress to genomic disorders, including WS (20-22).

Although the overall clinical presentation may be variable, the distinctive phenotype was evident in all of our patients. Perinatal problems such as cesarian section, premature delivery, low birth weight/small for gestational age, jaundice, and respiratory distress syndrome were common, but because they are nonspecific, they rarely led to the diagnosis of WS.

Because of feeding difficulties, WS patients are underweight during the first year of life. Recurrent vomiting as a result of gastroesophageal reflux, colic, and diarrhea is also common (23). GH deficiency has not been considered a major cause of growth retardation in WS, and in the literature, only one patient with confirmed GH deficiency responded well to therapy (24). It is noteworthy that one of our patients (patient 27) responded satisfactorily to hGH therapy. The deletion in this specific patient extended beyond D7S1870 to D7S489A polymorphic markers. Weight gain was observed in most cases after the age of 10 , in contrast with the OFC and the height, which followed the anticipated growth parameters (23). It has been reported that the mean final height of girls and boys with WS is 153.9 $\pm 6.9 \mathrm{~cm}$ and $168.2 \pm 6.9 \mathrm{~cm}$, respectively (25).

All of our patients were tested thoroughly for thyroid abnormalities because it has been reported that WS patients have elevated levels of TSH (26). As it is known, WS patients have a tendency to central precocious puberty and abbreviated pubertal growth spurt, especially in boys $(27,28)$. The early pubertal development and the short duration of this period contribute to the decreased final height (27). In our study, eight (16\%) patients had precocious puberty which seems to be higher than the one reported in the literature (29). Three children were treated with GnRH agonists, as hormonal intervention to delay puberty allows for further intellectual and emotional maturity (29). Because the majority of our patients (32 of 50) were younger than $10 \mathrm{y}$, early menstruation could not be excluded.

Cardiovascular anomalies were evident in most of our WS patients, as in other reports in the literature (30-33). The incidence of total cardiovascular disease in boys was greater than in girls (34). Although SVAS is reported to be the most common cardiovascular defect in WS (35-73\%), in our group, only $28 \%$ had SVAS (35). In six boys, SVAS was accompanied by hypoplastic aortic arch and was severe enough (gradient $>25 \mathrm{~mm} \mathrm{Hg}$ ) to require surgical intervention. It has been reported that gradients $>20 \mathrm{~mm} \mathrm{Hg}$ in SVAS and WS tend to increase with time (36). It is well documented that PPS shows a good long-term prognosis $(35,36)$. Only one girl (patient 3 ) required surgical intervention for PS.

Patient 15 received a diagnosis of having PPS as a neonate, but at the age of 4 the PPS was not identifiable. Long-term cardiovascular monitoring showed that cardiac manifestations, if present, were evident by the age of ten $(37,38)$.

It is reported that unexpected deaths are attributed to myocardial ischemia, decreased cardiac output, and arrhythmia. Sudden death, a well-known outcome of nonsyndromic SVAS, is not common in WS patients. However, some WS patients have died from strokes (39-44). Five of our male patients, died: one boy (patient 8) with SVAS (gradient $40 \mathrm{~mm} \mathrm{Hg}$ ) and 
severe left ventricular hypertrophy who underwent cardiac catheterization and angiography. Surgical correction was complicated by multiorgan failure. He developed seizures and was under antiepileptic therapy. At the age of 3 , he was treated for endocarditis but 2 y later died as a result of septicemia. Another one, patient 29, was operated on successfully twice: $t$ the age of 5 mo because of severe SVAS and at the age of 3 because of gastrointestinal bleeding attributed to Meckel diverticulum. Unfortunately, at the age of 4 , he suddenly died as a result of myocardial ischemia.

Patient 34 received a diagnosis at the age of $3.5 \mathrm{mo}$ as a result of SVAS and PS. He died at the age of 3 as a result of the second balloon angioplasty. Patient 47 failed to thrive and died suddenly at the age of $2.5 \mathrm{y}$. He had no cardiac defect, and no autopsy was performed.

A 3-y-old boy (patient 4) was operated on because of SVAS and VSD. Joint laxity, generalized arteriopathy, and hypertension were aggravated by brain hemorrhage and hemiplegia (Fig. 5). After palliative neurosurgical intervention, he never regained consciousness. Cardiac catheterization revealed aortic hypoplasia and severe left ventricular hypertrophy. Death was a result of intractable hypertension, which was attributed to bilateral and severe $(>90 \%$ and $1 \mathrm{~cm}$ in length) renal artery stenosis (Fig. 6). The severity of elastin arteriopathy in patients with WS is worse in male individuals and the presence of aortic hypoplasia impairs the prognosis of those who operated on for SVAS as in our patient $4(34,36)$.

It has been reported that early-onset hypertension is evident in $40 \%$ of WS patients, between infancy and the age of 34 $(38,45)$. Hypertension in six of our patients was evident before the age of 5, although Broder et al. (46) stated that high blood pressure is more frequent in adolescents and adults. Patient 25, a 30-y-old married woman, had one of the highest IQs (IQ = 80). After a therapeutic abortion at the age of 27 as a result of

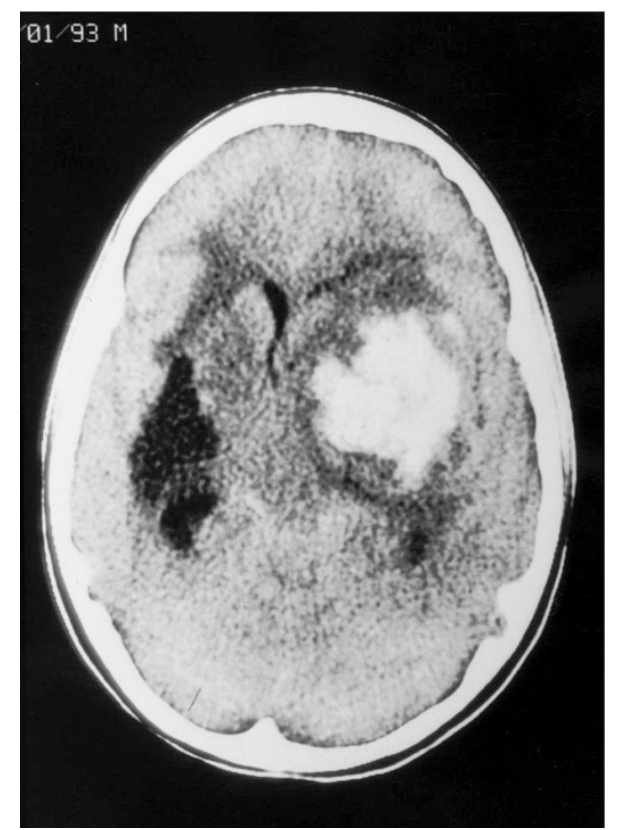

Figure 5. Acute hemorrhage at the left hemisphere. The lesion at the right hemisphere represents hemorrhage at a chronic stage.

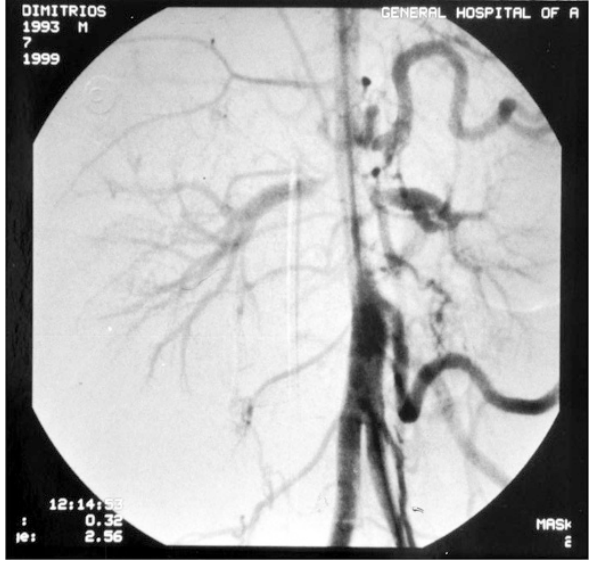

Figure 6. Stenosis at the proximal portion of both renal arteries.

preeclampsia, she developed intractable hypertension. This patient, along with the two reported cases by Pankau et al. (3) in which autosomal dominant inheritance was observed confirms that female individuals with WS are often fertile.

Genitourinary abnormalities were evident in $20 \%$ of our patients, consistent with the reported incidence $(47,48)$. A 5-y-old girl (patient 36) had nephrocalcinosis in renal ultrasound and hypercalciuria with normocalcemia. Morris et al. (49) described this in adults with WS.

Our affected children had delayed cognitive and language abilities that improved with time. Hyperactivity was more situational than pervasive. Impaired visuospatial abilities are probably responsible for learning difficulties. Stromme et al. (50) attributes $6 \%$ of mental retardation of genetic cause to WS. In the spatial deficit characteristic of WS, LIMkinase 1 gene has been implicated $(14,17)$. Defining the biologic basis for the specific defects, along with the behavioral profile found in individuals with WS, would explain how cognition is linked ultimately to the genes $(51,52)$. Hyperacusis during childhood was consistent in our series $(90 \%)(53,54)$.

One of our boys (patient 17) developed a non-Hodgkin's lymphoma. This is the second reported case of a lymphoma in a WS patient and the first in a child, whereas there have been three more reports of malignancy associated with WS (55-58).

Patients 21 and 22 were monozygotic twins as confirmed by molecular studies. Although their dysmorphic features differed slightly, the cognitive profile was comparable. This is the ninth set of twins with WS reported in the literature (59-61). Hypercalcemia was less frequent $(6 \%)$ in our patients than the documented incidence in WS (15\%) (62). Stellate iris, which is considered pathognomonic, does not affect the vision. No retinal vascular tortuosity was found in our patients $(38,63,64)$.

Connective tissue abnormalities are very common. Morris et al. $(49,65)$ stated that joint contractures could be accompanied by kyphoscoliosis and lordosis. Osebold et al. (66) urged spinal surgeons to operate early because of the rapid progression of kyphoscoliosis. Manifestations of the joints and the skin were evident in our series. Premature aging of the skin, hypo- or hyperpigmented areas, one case with acanthosis nigricans (patient 3), and one with hairy pigmented nevus (patient 42) were noted. Cutis laxa phenotype could result from mutations in the 
elastin gene or the deletion of the entire gene $(67,68)$. Knockout mice show that the elastin gene plays an important role in the elasticity of various tissues. This could be used as preventive therapy in SVAS, WS, and other muscular disorders (69). Neurologic findings such as hypotonia, fine motor and oromotor dysfunction, reflex activity, microcephaly, and seizures were evident in our patients.

On the basis of the observations of the present study, it seems that a precise evaluation of WS patients results in an earlier diagnosis and appropriate care management and counseling, as has been previously reported (70). WS remained undiagnosed in patients 9,25 , and 38 until adolescence. In the literature, there are also reports of WS diagnosis in adults $(65,71,72)$.

Although the contribution of FISH remains invaluable for confirmation of the diagnosis, it does not permit estimation of the size of the deletion or the parental origin. Molecular analysis allowed a correlation of genotype with phenotype.

On the basis of the molecular findings, we noted that whereas the average age of diagnosis in our series was 6 , in the patients with paternal deletion, the mean age was 8.3. Also, when there were no heart defects, the diagnosis of some WS with paternal deletions was made later. Concerning the mean birth weight, no difference was noted between the two groups ( $2.44 \mathrm{~g}$ in the paternal and $2.53 \mathrm{~g}$ in the maternal). More of our patients with maternal deletions exhibited microcephaly, a finding also reported by Jurado et al. (7). When microcephaly was not present, in the maternally deleted group, IQs were $\geq 70$. Three of the 17 paternal deletion cases had the highest IQs (75-85). Also, all sudden deaths occurred in boys with maternal deletions. In the paternally derived deletions, more patients with aortic stenosis $(n=5)$ rather than PS $(n=2)$ were noted. In light of the clinical differences between paternally and maternally inherited deletions and the worse outcome of maternal ones, it seems that some genes in the Williams cluster may be imprinted $(7,73)$. Further research is needed to clarify this observation.

The unequal meiotic recombination/crossover, probably mediated by the highly homologous DNA (LCRs) that flank the commonly deleted region, occurs mostly in the maternal chromosome. The recurrence of the inter- $(66 \%)$ or intrachromosomal $(33 \%)$ rearrangement must be negligible $(20,73)$. This agrees with the sporadic occurrence of WS in the literature and in our series.

The most informative loci were D7S1870 and D7S2476, followed by D7S489B and D7S613. D7S2472 was not informative in our population. It is interesting that only two patients (27 and 41) had hemizygosity in the D7S489A locus, whereas the rest were either noninformative or normal. This verifies that locus D7S489A is outside the deletion in most WS patients (7). Robinson et al. (74) identified two more cases with hemizygosity at D7S489A (called D7S489L). In our series, patient 27 was informative for the most centromeric D7S1870 and the most telomeric marker D7S489A. One can probably speculate that the size of this deletion explains the GH deficiency found in this child. More studies should be carried out, however, to determine whether in the deleted area, there are genes that control the height.
It was difficult to determine the size of the deletion in all our patients, because some were noninformative for the most telomeric and/or the most centromeric polymorphisms. Even though it is premature or difficult to establish genotypephenotype correlations, the dissection of the variable phenotype will provide WS patients with a reliable prognosis of the severity of their symptoms.

Acknowledgments. We thank the families who participated in this study for cooperation. We also appreciated the clinical examination of our patients by the pediatric cardiologists, neurologists, and endocrinologists.

\section{REFERENCES}

1. Williams JC, Barratt-Boyes BG, Lowe JB 1961 Supravalvular aortic stenosis. Circulation 24:1311-1318

2. American Academy of Pediatrics Committee on Genetics 2001 Health care supervision for children with Williams syndrome. Pediatrics 107:1192-1204

3. Pankau R, Siebert R, Kautza M, Schneppeheim R, Gosch A, Wessel A, Partsch CJ 2001 Familial Williams-Beuren syndrome showing varying clinical expression. Am J Med Genet 98:324-329

4. Duba HC, Doll A, Neyer M, Erdel M, Mann C, Hammerer I, Utermann G, Grzeschik KH 2002 The elastin gene is disrupted in a family with balanced translocation $\mathrm{t}(7 ; 16)$ (q11.23;q13) associated with a variable expression of the Williams-Beuren syndrome. Eur J Hum Genet 10:351-361

5. Morris CA, Thomas IT, Greenberg F 1993 Williams syndrome: autosomal dominant inheritance. Am J Med Genet 47:478-481

6. Nickerson E, Greenberg F, Keating MT, McCaskill C, Shaffer LG 1995 Deletions of the elastin gene at 7q11.23 occur in approximately $90 \%$ of patients with Williams syndrome. Am J Hum Genet 56:1156-1161

7. Perez Jurado LA, Peoples R, Kaplan P, Hamel BC, Francke U 1996 Molecular definition of the chromosome 7 deletion in Williams syndrome and parent-of-origin effects on Growth. Am J Hum Genet 59:781-792

8. Ewart AK, Morris CA, Atkinson D, Jin W, Sternes K, Spallone P, Stock AD, Leppert M, Keating MT 1993 Hemizygosity at the elastin locus in a developmental disorder, Williams syndrome. Nat Genet 5:11-16

9. Tassabehji M, Metcalfe K, Donnai D, Hurst J, Reardon W, Burch M, Read AP 1997 Elastin: genomic structure and point mutations in patients with supravalvular aortic stenosis. Hum Mol Genet 6:1029-1036

10. Metcalfe K, Rucka AK, Smoot L, Hofstadler G, Tuzler G, McKeown P, Siu V, Rauch A, Dean J, Dennis N, Ellis I, Reardon W, Cytrynbaum C, Osborne L, Yates JR, Read AP, Donnai D, Tassabehji M 2000 Elastin: mutational spectrum in supravalvular aortic stenosis. Eur J Hum Genet 8:955-963

11. Morris CA, Mervis CB 2000 Williams syndrome and related disorders. Annu Rev Genomics Hum Genet 1:461-484

12. Donnai D, Karmiloff-Smith A 2000 Williams syndrome: from genotype through to the cognitive phenotype. Am J Med Genet 97:164-171

13. Merla G, Ucla C, Guipponi M, Reymond A 2002 Identification of additional transcripts in the Williams-Beuren syndrome critical region. Hum Genet 110:429438

14. Frangiskakis JM, Ewart AK, Morris CA, Mervis CB, Bertrand J, Robinson BF, Klein BP, Ensing GJ, Everett LA, Green ED, Proschel C, Gutowski NJ, Noble M, Atkinson DL, Odelberg SJ, Keating MT 1996 LIM-kinase 1 hemizygosity implicated in impaired visuospatial constructive cognition. Cell 86:59-69

15. Meng X, Lu X, Li Z, Green ED, Massa H, Trask BJ, Morris CA, Keating MT 1998 Complete physical map of the common deletion region in Williams syndrome and identification and characterization of three novel genes. Hum Genet 103:590-599

16. Tassabehji M, Metcalfe K, Karmiloff-Smith A, Carette MJ, Grant J, Dennis N, Reardon W, Splitt M, Read AP, Donnai D 1999 Williams syndrome: use of chromosomal microdeletions as a tool to dissect cognitive and physical phenotypes. Am J Hum Genet 64:118-125

17. Wang JY, Frenzel KE, Wen D, Falls DL 1998 Transmembrane neuregulins interact with LIM kinase 1, a cytoplasmic protein kinase implicated in development of visuospatial cognition. J Biol Chem 273:20525-20534

18. Shabahang S, Huwiler A, Pfeilschifter J 2002 Identification of the LIM kinase-1 as a ceramide-regulated gene in renal mesangial cells. Biochem Biophys Res Commun 298:408-413

19. Miller SA, Dykes DD, Polesky HF 1988 A simple salting out procedure for extracting DNA from human nucleated cells. Nucleic Acids Res 16:1215

20. Dutly F, Schinzel A 1996 Unequal interchromosomal rearrangements may result in elastin gene deletions causing the Williams-Beuren syndrome. Hum Mol Genet 5:1893-1898

21. Urban Z, Helms C, Fekete G, Csiszar K, Bonnet D, Munnich A, Donis-Keller H, Boyd CD 1996 7q11.23 deletions in Williams syndrome arise as a consequence of unequal meiotic crossover. Am J Hum Genet 59:958-962

22. Stankiewicz P, Lupski JR 2002 Genome architecture, rearrangements and genomic disorders. Trends Genet 18:74-82 
23. Pankau R, Partsch CJ, Neblung A, Gosch A, Wessel A, Schaub J 1994 Natural history of body mass index in Williams-Beuren syndrome. Am J Med Genet 52:51-54

24. Kuijpers GM, De Vroede M, Knol HE, Jansen M 1999 Growth hormone treatment in a child with Williams-Beuren syndrome: a case report. Eur J Pediatr 158:451-454

25. Pankau R, Partsch CJ, Gosch A, Oppermann HC, Wessel A 1992 Statural growth in Williams-Beuren syndrome. Eur J Pediatr 151:751-755

26. Cammareri V, Vignati G, Nocera Q, Beck-Peccoz P, Persani L 1999 Thyroid hemiagenesis and elevated thyrotropin levels in a child with Williams syndrome. Am J Med Genet 85:491-494

27. Cherniske EM, Sadler LS, Schwartz D, Carpenter TO, Pober BR 1999 Early puberty in Williams syndrome. Clin Dysmorphol 8:117-121

28. Partsch CJ, Japing I, Siebert R, Gosch A, Wessel A, Sippell WG, Pankau R 2002 Central precocious puberty in girls with Williams syndrome. J Pediatr 141:441-443

29. Scothorn DJ, Butler MG 1997 How common is precocious puberty in patients with Williams syndrome? Clin Dysmorphol 6:91-93

30. Kumar A, Stalker HJ, Williams CA 1993 Concurrence of supravalvular aortic stenosis and peripheral pulmonary stenosis in three generations of a family: a form of arterial dysplasia. Am J Med Genet 45:739-742

31. Fryssira H, Palmer R, Hallidie-Smith KA, Taylor J, Donnai D, Reardon W 1997 Fluorescent in situ hybridisation (FISH) for hemizygous deletion at the elastin locus in patients with isolated supravalvular aortic stenosis. J Med Genet 34:306-308

32. Chowdhury T, Reardon W 1999 Elastin mutation and cardiac disease. Pediatr Cardiol 20:103-107

33. Towbin JA, Casey B, Belmont J 1999 Human genetics '99: the cardiovascular system. The molecular basis of vascular disorders. Am J Hum Genet 64:678-684

34. Sadler LS, Pober BR, Grandinetti A, Scheiber D, Fekete G, Sharma AN, Urban Z 2001 Differences by sex in cardiovascular disease in Williams syndrome. J Pediatr 139:849-853

35. Eronen M, Peippo M, Hiippala A, Raatikka M, Arvio M, Johansson R, Kähkönen M 2002 Cardiovascular manifestation in 75 patients with Williams syndrome. J Med Genet 39:554-558

36. Wessel A, Pankau R, Kececioglou D, Ruschewski W, Bürsch JH 1994 Three decades of follow-up of aortic and pulmonary vascular lesions in the Williams-Beuren syndrome. Am J Med Genet 52:297-301

37. Bockoven JR, Kaplan P, Namey T, Gleasal M 1997 Williams syndrome: the firs decade is crucial for cardiovascular monitoring. Proc Greenwood Genet Center 16:134-135

38. Lashkari A, Smith AK, Graham JM Jr 1999 Williams-Beuren syndrome: an update and review for the primary physician. Clin Pediatr (Phila) 38:189-208

39. Kaplan P, Levinson M, Kaplan BS 1995 Cerebral artery stenoses in William syndrome cause strokes in childhood. J Pediatr 126:943-945

40. Wollack JB, Kaifer M, LaMonte MP, Rothman M 1996 Stroke in Williams syndrome. Stroke 27:143-146

41. Bonnet D, Cormier V, Villain E, Bonhoeffer P, Kachaner J 1997 Progressive left main coronary artery obstruction leading to myocardial infarction in a child with Williams syndrome. Eur J Pediatr 156:751-753

42. Suarez-Mier MP, Morentin B 1999 Supravalvular aortic stenosis, Williams syndrome and sudden death. A case report. Forensic Sci Int 106:45-53

43. Bird LM, Billman GF, Lacro RV, Spicer RL, Jariwala LK, Hoyme HE, ZamoraSalinas R, Morris C, Viskochil D, Frikke MJ, Jones MC 1996 Sudden death in Williams syndrome: report of ten cases. J Pediatr 129:926-931

44. Kantharia BK, Mittleman RS 1999 Concomitant reentrant tachycardias from concealed accessory atrioventricular bypass tract and atrioventricular nodal reentry in a patient with Williams syndrome. Cardiology 91:264-267

45. Wessel A, Pankau R, Berdau W, Lons P 1997 Aortic stiffness with the WilliamsBeuren syndrome. Pediatr Cardiol 18:244

46. Broder K, Reinhardt E, Ahern J, Lifton R, Tamborlane W, Pober B 1999 Elevated ambulatory blood pressure in 20 subjects with Williams syndrome. Am J Med Genet $83: 356-360$

47. Pober BR, Lacro RV, Rice C, Mandell V, Teele RL 1993 Renal findings in 40 individuals with Williams syndrome. Am J Med Genet 46:271-274

48. Pankau R, Partsch CJ, Winter M, Gosch A, Wessel A 1996 Incidence and spectrum of renal abnormalities in Williams-Beuren syndrome. Am J Med Genet 63:301-304
49. Morris CA, Demsey SA, Leonard CO, Dilts C, Blackburn BL 1988 Natural history of Williams syndrome: physical characteristics. J Pediatr 113:318-326

50. Stromme P, Bjornstad PG, Ramstad K 2002 Prevalence estimation of Williams syndrome. J Child Neurol 17:269-271

51. Bellugi U, Lichtenberger L, Mills D, Galaburda A, Korenberg J 1999 Bridging cognition, the brain and molecular genetics: evidence from Williams syndrome. Trends Neurosci 22:197-207

52. Galaburda AM, Bellugi U 2000 Multi-level analysis of cortical neuroanatomy in Williams syndrome. J Cogn Neurosci 12:74-88

53. Van Borsel J, Curfs LM, Fryns JP 1997 Hyperacusis in Williams syndrome: a sample survey study. Genet Couns 8:121-126

54. Miani C, Passon P, Bracale AM, Barotti A, Panzolli N 2001 Treatment of hyperacusis in Williams syndrome with bilateral conductive hearing loss. Eur Arch Otorhinolaryngol 258:341-344

55. Amenta S, Moschovi M, Sofocleous C, Kostaridou S, Mavrou A, Fryssira H 2004 Non-Hodgkin lymphoma in a child with Williams syndrome. Cancer Genet Cytogenet 154:86-88

56. Semmekrot BA, Rotteveel JJ, Bakker-Niezen SH, Logt F 1985-1986 Occurrence of an astrocytoma in a patient with Williams syndrome. Pediatr Neurosci 12:188-191

57. Felice PV, Ritter SD, Anto J 1994 Occurrence of non-Hodgkin's lymphoma in Williams syndrome-case report. Angiology 45:167-170

58. Culic V, Culic S, Armanda V, Resic B, Lasan R, Peterlin B 2002 Single signal of the Williams syndrome chromosome region 1 gene in hyperploidic bone marrow cells of acute lymphoblastic leukemia in a Williams syndrome patient. Med Pediatr Oncol 38:205-207

59. Castorina P, Selicorni A, Bedeschi F, Dalprá L, Larizza L 1997 Genotype-phenotype correlation in two sets of monozygotic twins with Williams syndrome. Am J Med Genet 69:107-111

60. Pankau R, Gosch A, Simeoni E, Wessel A 1993 Williams-Beuren syndrome in monozygotic twins with variable expression. Am J Med Genet 47:475-477

61. Murphy MB, Greenberg F, Wilson G, Hughes M, Diliberti J 1990 Williams syndrome in twins. Am J Med Genet Suppl 6:97-99

62. Cassidy SB, Allanson JE 2001 Management of Genetic Syndromes. Wiley-Liss, New York, pp 518

63. Winter M, Pankau R, Amm M, Gosch A, Wessel A 1996 The spectrum of ocular features in the Williams-Beuren syndrome. Clin Genet 49:28-31

64. Kapp ME, von Noorden GK, Jenkins R 1995 Strabismus in Williams syndrome. Am J Ophthalmol 119:355-360

65. Morris CA, Leonard CO, Dilts C, Demsey SA 1990 Adults with Williams syndrome. Am J Med Genet Suppl 6:102-107

66. Osebold WR, King HA 1994 Kyphoscoliosis in Williams syndrome. Spine 19:367-

67. Zhang J, Kumar A, Roux K, Williams CA, Wallace MR 1999 Elastin region deletions in Williams syndrome. Genet Test 3:357-359

68. Dridi SM, Ghomrasseni S, Bonnet D, Aggoun Y, Vabres P, Bodemer C, Lyonnet S, de Prost Y, Fraitag S, Pellat B, Sidi D, Godeau G 1999 Skin elastic fibers in Williams syndrome. Am J Med Genet 87:134-138

69. Faury G 2001 Role of elastin in the development of vascular function. Knock-out study of the elastin gene in mice. J Soc Biol 195:151-156

70. Huang L, Sadler L, O'Riordan M, Robin NH 2002 Delay in diagnosis of Williams syndrome. Clin Pediatr (Phila) 41:257-261

71. Davies M, Howlin P, Udwin O 1997 Independence and adaptive behavior in adults with Williams syndrome. Am J Med Genet 70:188-195

72. Pankau R, Partsch CJ, Gosch A, Siebert R, Scheider M, Schneppenheim R, Winter M, Wessel A 2000 Williams-Beuren syndrome 35 years after the diagnosis in one of the first Beuren patients. Am J Med Genet 91:322-324

73. Tassabehji M 2003 Williams-Beuren syndrome: a challenge for genotype-phenotype correlations. Hum Mol Genet 12:R229-R237

74. Robinson WP, Waslynka J, Bernasconi F, Wang M, Clark S, Kotzot D, Schinzel A 1996 Delineation of 7q11.2 deletions associated with Williams-Beuren syndrome and mapping of a repetitive sequence to within and to either side of the common deletion. Genomics 34:17-23 